\title{
Photovoltaic Effect in Isotype Phthalocyanine Heterojunctions
}

\author{
Andrey I. Koptyaev, ${ }^{a}$ Mahmud Khamdoush, ${ }^{a}$ Anton N. Fedoseev, ${ }^{\text {b }}$ Vlad V. Travkin, ${ }^{\text {b }}$ \\ and Georgy L. Pakhomova,b@ \\ ${ }^{a}$ Institute of Macroheterocycles, Ivanovo State University of Chemistry and Technology (ISUCT), 153000 Ivanovo, Russian \\ Federation \\ ' Institute for Physics of Microstructures of the Russian Academy of Sciences (IPM RAS), 603950 Nizhny Novgorod, Russian \\ Federation \\ ${ }^{@}$ Corresponding authorE-mail:pakhomov@ipmras.ru
}

\begin{abstract}
The J-V characteristics of planar heterojunctions consisting of molecular semiconductors, tin (or lead) phthalocyanine and boron chloride subphphalocyanine SubPc, are obtained. While almost non-rectifying in the dark, the illuminated junctions show an unexpectedly significant photovoltaic effect $(0.4 \mathrm{~V})$. The sign of the photovoltage is also different from what is expected considering the donor/acceptor properties of paired compounds. This observation should be taken into account when introducing phthalocyanines in multilayer photovoltaic cells as buffers or cascade components.
\end{abstract}

Keywords: Molecular heterojunctions, phthalocyanines, cascade solar cells.

\section{Фотовольтаический эффект в изотипных фталоцианиновых гетеропереходах}

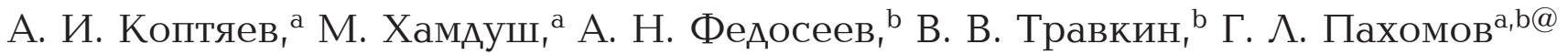 \\ ${ }^{a}$ НИИ химии макрогетероциклических соединений, Ивановский государственный химико-технологический \\ университет, 153000 Иваново, Российская Федерация \\ ' Институт физики микроструктур РАН, 603950 Нижний Новгород, Российская Федераџия \\ @E-mail: pakhomov@ipmras.ru
}

\begin{abstract}
Получены вольтамперные характеристики планарных гетеропереходов, состоящих из пары молекулярных полупроводников, фталочиианината олова (или свинца) и субфталоцианината бора. Несмотря на то, что в темноте выпрямляющие свойства гетероперехода не проявляются, при освещении неожиданно получен довольно значительный фотовольтаический эффект (0.4 В). Знак фото-э.д.с. также отличается от ожидаемого на основании донорно-акцепторных свойств контактирующих комплексов. Это наблюдение следует учитывать при введении фталоцианинов в многослойные фотовольтаические ячейки в качестве буферов или компонентов каскада.
\end{abstract}

Ключевые слова: Молекулярные гетеропереходы, фталоцианины, каскадные солнечные ячейки.

\section{Introduction}

Metal phthalocyanines (MetPcs) and their nearest analogs - boron chloride subphthalocyanines (SubPcs) are widely used in organic electronic devices with a planar molecular heterojunction (PHJ). ${ }^{[1]}$ The anisotype phthalocyainine-based PHJ containing two different-type $(p$ - and $n$-) semiconductors are conventionally employed, whereas the isotype heterojunctions formed with two semiconductors of the same conductivity type $(p-/ \mathrm{P}$ or $n-/ \mathrm{N})$ have been studied very little so far. There is some information on the use of phthalocyanine-based isotype PHJ in the organic field-effect thin-film transistors. ${ }^{[2,3]}$ Photovoltaic cells, or even measurements of the photovoltaic effect in isotype PHJ with two phthalocyanine semiconductors, to the best of our knowledge, have not been reported yet. ${ }^{[4]}$ 


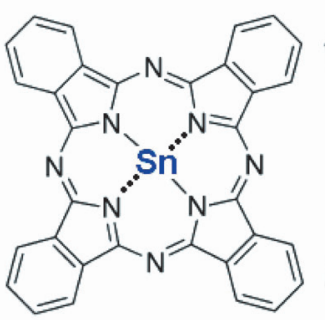

$\mathrm{SnPC}$

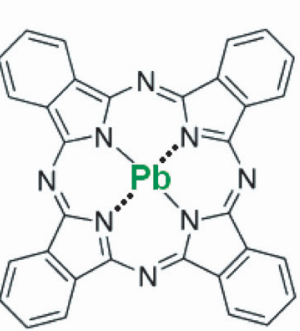

$\mathrm{PbPc}$

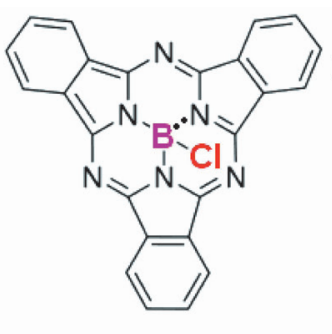

SubPc

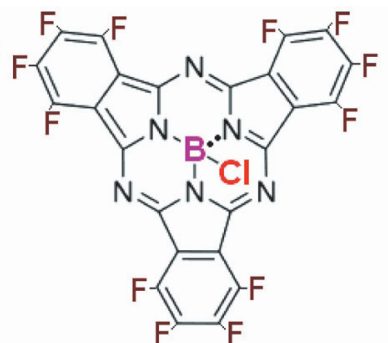

SubPcF 12

Scheme 1.

Meanwhile, there recently appeared a concept of a cascade organic solar cell. ${ }^{[1]}$ According to it, thin molecular layers are consecutively deposited on top of each other to form the multiple energetically cascading junctions that enable a more efficient two-step exciton dissociation ${ }^{[5-10]}$ and/or charge transport. ${ }^{[5,6,9,11]}$ Additional benefits are associated with the well-aligned excitation transfer (energy relay) [1,6,12] and/or with the broadening of the spectral range due to the complementary photoabsorbing layer(s)..$^{[6,7,10-14]}$

It should be stressed that of at least three components of the cascade, such as the donor/interlayer/acceptor, the two ones may be semiconductors of the same conductivity type, i.e., $p-/ \mathrm{P} / n$ or $p-/ n-/ \mathrm{N} .{ }^{[15]}$ Peripherally unsubstituted MetPcs are generally known as the $p$-type (or donor) materials, ${ }^{[1,2,5,9-11]}$ whereas SubPcs demonstrate a rather complicated (bipolar ${ }^{[6,8,15]}$ ) behavior, acting as either a donor or acceptor depending on the redox properties of adjacent molecules. ${ }^{[1,6,8,9,13-18]}$ Both kinds of complexes have a long history of use in the cascade $\mathrm{PHJ} .^{[1]}$

There are also reports on the insertion of the $p$-type phthalocyanine as a buffer layer between the anode and the donor of the main PHJ, in which this donor is another ( $p$-type) phthalocyanine semiconductor. ${ }^{[11,14,16,17]}$

In all of the above examples the concentration of charge carriers and the positions of the energy levels in the adjacent ( $p$-type) molecular semiconductors are different. ${ }^{[2-4]}$ Therefore it is not unrealistic to assume that an isotype $p$-/P heterojunction can be formed at the interface between SubPc and conventional metal phthalocyanine. ${ }^{[3]}$ In this work, we have fabricated and tested the archetypal thinfilm devices containing the MetPc/SubPc junction with a view to elucidating its own rectifying and photovoltaic activity.

\section{Experimental}

The devices were fabricated using the vacuum techniques as described earlier. ${ }^{[19-21]}$ Tin phthalocyanine (SnPc), lead phthalocyanine $(\mathrm{PbPc})$ and boron chloride subphthalocyanine (SubPc) were purchased from Aldrich and used as received (Scheme 1). In some experiments, we used a subphthalocyanine derivative fully fluorinated on periphery $\left(\mathrm{SubPcF}_{12}{ }^{[1]}\right)$, which was synthesized and purified at ISUCT. ${ }^{[19]}$ Standard Aldrich ITO coated glass slides served as substrates. The MetPc/SubPc bilayer (or its analogues) deposited in different sequences was sandwiched between the bottom ITO/ $\mathrm{MoO}_{\mathrm{x}}$ and top $\mathrm{MoO}_{\mathrm{x}} / \mathrm{Ag} / \mathrm{MoO}_{\mathrm{x}}$ electrode. ${ }^{[20]}$ The thickness of the $\mathrm{MoO}_{\mathrm{x}}$ layer on ITO was $5 \mathrm{~nm}$, the thickness ratio in the trilayer top electrode was $15 / 10 / 5 \mathrm{~nm}$. Thicknesses of molecular layers varied as follows: SnPc or PbPc $40 \mathrm{~nm}$, SubPc $20 \mathrm{~nm}$ and Sub$\mathrm{PcF}_{12} 20 \mathrm{~nm}$. To obtain reliable characteristics for the devices with the $\mathrm{SubPcF}_{12}$ bottom layer, the $\mathrm{MoO}_{\mathrm{x}}$ buffer in the bottom electrode was omitted. In a likewise matter, $\mathrm{MoO}_{\mathrm{x}}$ was removed from the top tri-layer electrode when the $\mathrm{SubPcF}_{12}$ layer was on top (Table 1). While the sequence of deposition was varied as described below, all other conditions during the device preparation were maintained exactly the same. The device area in all experiments was $0.14 \mathrm{~cm}^{2}$.

Photoelectrical measurements were carried out at room temperature using a Keithley SGS-4200 parameter analyzer and a Zolix AM1.5G solar simulator on a batch of devices trans-

Table 1. Values of $V_{o c}$ and $J_{s c}$ (polarity as in Figures 1-4, S4-S6). A series of four samples was measured for each device composition. The averaged values in the series are given along with the error intervals (in parentheses).

\begin{tabular}{|c|c|c|c|}
\hline $\mathrm{N}$ & Device composition & $V_{o c}, \mathrm{~V}$ & $J_{s c}, \mathrm{~mA} / \mathrm{cm}^{2}$ \\
\hline 1 & Glass $/ \mathrm{ITO} / \mathrm{MoO}_{\mathrm{x}} / \mathrm{SnPc} / \mathrm{SubPc} / \mathrm{MoO}_{\mathrm{x}} / \mathrm{Ag} / \mathrm{MoO}_{\mathrm{x}}$ & $-0.36( \pm 0.05)$ & $0.06( \pm 0.01)$ \\
\hline 2 & Glass $/ \mathrm{ITO} / \mathrm{MoO}_{\mathrm{x}} / \mathrm{SubPc} / \mathrm{SnPc} / \mathrm{MoO}_{\mathrm{x}} / \mathrm{Ag} / \mathrm{MoO}_{\mathrm{x}}$ & $0.39( \pm 0.05)$ & $-0.05( \pm 0.01)$ \\
\hline 3 & Glass $/ \mathrm{ITO} / \mathrm{MoO}_{\mathrm{x}} / \mathrm{PbPc} / \mathrm{SubPc} / \mathrm{MoO}_{\mathrm{x}} / \mathrm{Ag} / \mathrm{MoO}_{\mathrm{x}}$ & $-0.44( \pm 0.04)$ & $0.07( \pm 0.01)$ \\
\hline 4 & Glass/ITO/MoO $/ \mathrm{SnPc} / \mathrm{SubPcF}_{12} / \mathrm{Ag} / \mathrm{MoO}_{\mathrm{x}}$ & $0.43( \pm 0.04)$ & $-0.37( \pm 0.07)$ \\
\hline 5 & Glass $/ \mathrm{ITO} / \mathrm{MoO}_{\mathrm{x}} / \mathrm{SubPc} / \mathrm{SubPcF}_{12} / \mathrm{Ag} / \mathrm{MoO}_{\mathrm{x}}$ & $0.85( \pm 0.08)$ & $-0.18( \pm 0.03)$ \\
\hline 6 & Glass/ITO/SubPcF ${ }_{12} / \mathrm{SubPc} / \mathrm{MoO}_{\mathrm{x}} / \mathrm{Ag} / \mathrm{MoO}_{\mathrm{x}}$ & $-0.60( \pm 0.06)$ & $0.44( \pm 0.08)$ \\
\hline 7 & Glass/ITO/MoO $/ \mathrm{SnPc} / \mathrm{SubPc} / \mathrm{SubPcF}_{12} / \mathrm{Ag} / \mathrm{MoO}_{\mathrm{x}}$ & $0.67( \pm 0.01)$ & $-0.62( \pm 0.01)$ \\
\hline 8 & Glass/ITO/MoO $/ \mathrm{SubPc} / \mathrm{SnPc} / \mathrm{SubPcF}_{12} / \mathrm{Ag} / \mathrm{MoO}_{x}$ & $0.81( \pm 0.01)$ & $-0.29( \pm 0.02)$ \\
\hline
\end{tabular}



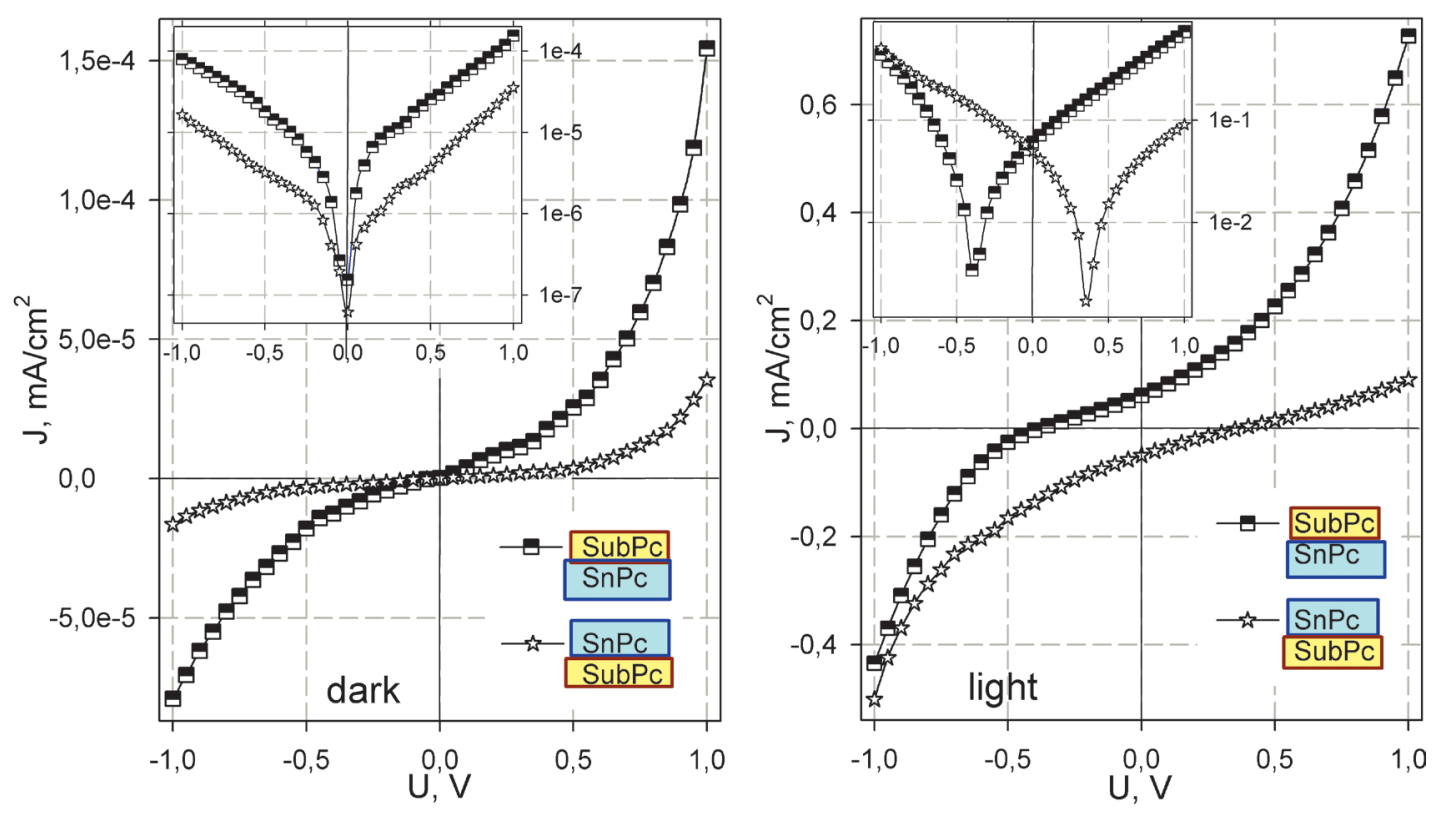

Figure 1. Comparison of $J-V$ characteristics of the devices with $\mathrm{SnPc} / \mathrm{SubPc}$ and $\mathrm{SubPc} / \mathrm{SnPc}$ bilayers (in the dark - left panel, under illumination - right panel). The sequence of layers is depicted in the graph. For better comparison, the insets show the dependences redrawn in the semilog scale.

ferred through air. The devices were illuminated from the ITO side. The basic absorption maximum (Q-band) of SnPc and SubPc photoabsorbers lies in different domains of the visible/NIR spectrum (see, Figure S2), the results on illumination of the devices with the monochromatic light (EQE) will be published elsewhere.

\section{Results and Discussion}

Figure 1 shows the dark and illuminated $J-V$ dependences for the devices with the SnPc/SubPc bilayer (squares). Forward bias corresponds to the positively charged bottom electrode - this polarity was fixed for all the devices described here. Dark $J-V$ dependences are almost symmetrical, which is expected for a sandwich-type device with quazi-ohmic electrodes and a non-rectifying $\mathrm{Pc} / \mathrm{Pc} *$ interface in the middle. ${ }^{[7,9,21,22,24]}$

Surprisingly, for the illuminated $\mathrm{SnPc} / \mathrm{SubPc}$ junction the $J-V$ dependences shift to quadrant II of the plot at the given polarity, i.e., the devices behave as formally 'inverted' photoelectrical cells. The absolute value of the open circuit voltage $V_{o c}$ is $0.36 \mathrm{~V}$ (Table 1).

Judging by the HOMO positions (Figure S3), SubPc should, presumably, be an acceptor, while more easily oxidized SnPc appears to act as a donor. Thus, the $p / n$ heterojunction (or D/A heterojunction ${ }^{[6]}$ ) could be anticipated in this pair, similarly to that reported (e.g., $\left.{ }^{[2]}\right)$ However, such a $p / n$ junction should result in the 'normal', not inverted, photovoltaic cell, for which the illuminated $J-V$ dependences are supposed to shift to quadrant IV.

One should keep in mind that the literature HOMOLUMO (calculated or measured) plots do not always reflect the actual transport energy levels in organic semiconductors. ${ }^{[1,23,24]}$ Furthermore, the bipolarity of SubPc in sandwich-type diodes was revealed in the air-free conditions (see, e.g., ${ }^{[6-9]}$ ). As concluded from the field-effect measure- ments in Ref. ${ }^{[25]}$ the majority charge carriers in extrinsic semiconductor SubPc are holes, a clear inversion from the $n$ to $p$-type occurs upon exposure to ambient air.

The equivalent devices, where another classical donor lead phthalocyanine ${ }^{[1]}$ was used to form the $\mathrm{PbPc} / \mathrm{SubPc}$ junction, demonstrated the same trend as in Figure 1 with illuminated $J-V$ dependences shifted to the II quadrant of the plot (Figure S4). Note, the devices exhibit relatively high ratio of photocurrent-to-dark current densities $\left(<10^{4} @ \pm 0.1 \mathrm{~V}\right.$, Figure S4). As illumination in various spectral domains shows, the majority of the photocurrent in the devices is associated with contribution of the SubPc (or $\mathrm{SubPcF}_{12}$ ) layer (Figure S5).

Then, we reversed the bilayer without changing the device composition at all (Figure 1, stars). The dark $J-V$ dependences are again nearly symmetrical, but under illumination they shift to the IV quadrant of the plot, which is typical to the 'normal' device. This implies that the $n / p$ junction expected for the $\mathrm{SubPc} / \mathrm{SnPc}$ bilayer does not occur.

To further prove the observed effect, the $p$-type tin phthalocyanine in the bilayer was replaced with an $n$-type perfluorinated subphthalocyanine $\mathrm{SubPcF}_{12}{ }^{[1]}$ The results are shown in Figure 2 (diamonds) in comparison with the characteristics of the parent $\mathrm{SnPc} / \mathrm{SubPc}$ device. At the given polarity, the devices incorporating the $\mathrm{SubPcF}_{12} / \mathrm{SubPc}$ bilayer show typical for the inverted cells characteristics in the dark (rectifying $n / p$ junction) and $V_{o c}$ of $0.60 \mathrm{~V}$ under illumination. The latter value is comparable to those reported in the literature for similar photovoltaic cells. ${ }^{[1,19,22]}$ The short circuit current $J_{s c}$ largely increases compared to the parent device with $\mathrm{SnPc} / \mathrm{SubPc}$ junction, but its absolute value is still very low (Table 1). The most likely reasons are the non-optimized thickness of layers and the absence of the appropriate buffer at the ITO/SubPcF ${ }_{12}$ interface. This also explains the $S$-shaped profile of the illuminated $J-V$ dependences 

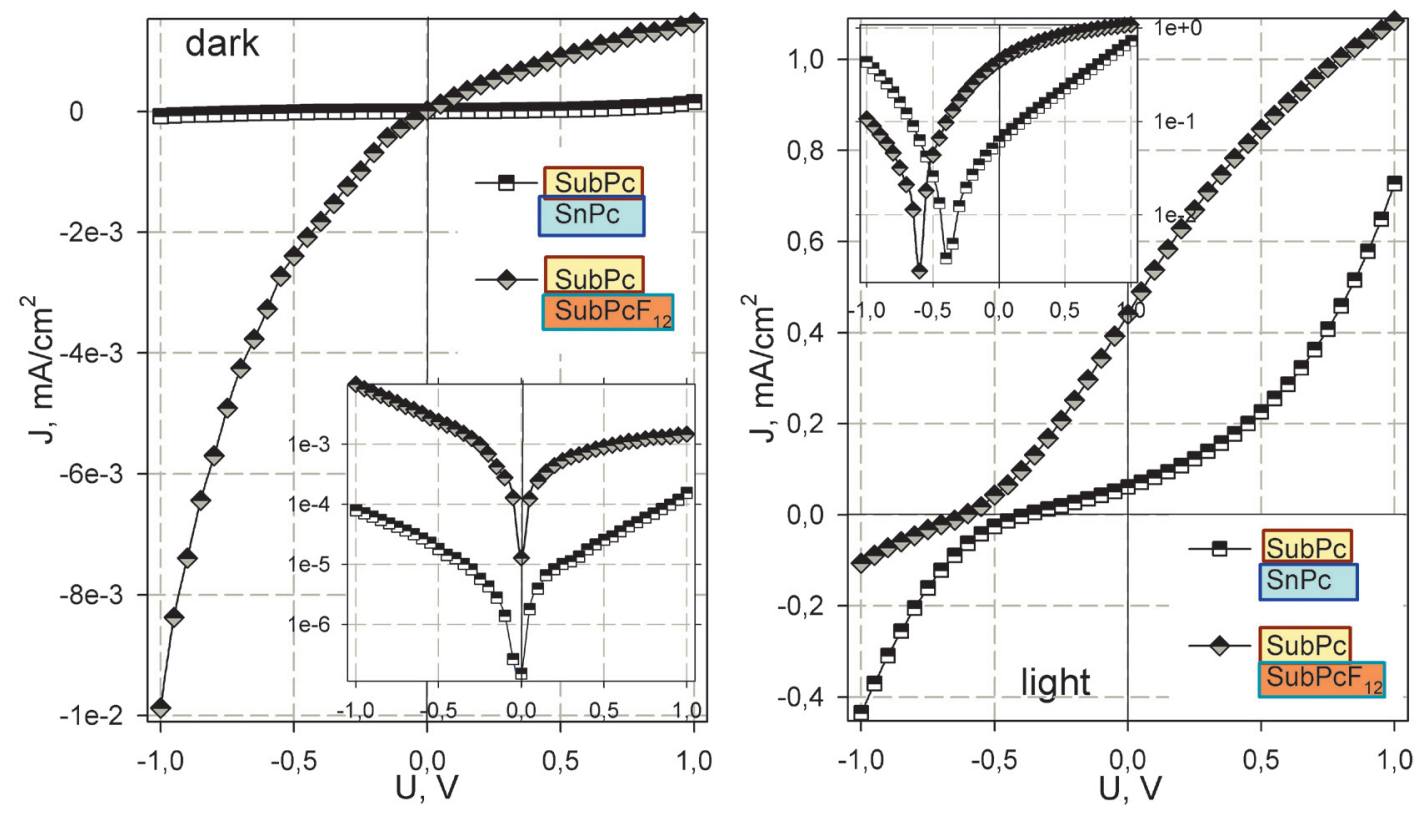

Figure 2. Comparison of $J-V$ characteristics of the devices with $\mathrm{SnPc} / \mathrm{SubPc}$ and $\mathrm{SubPcF}_{12} / \mathrm{SubPc}$ bilayers (in the dark - left panel, under illumination - right panel). The sequence of layers is depicted in the graph. For better comparison, the insets show the dependences redrawn in the semilog scale.
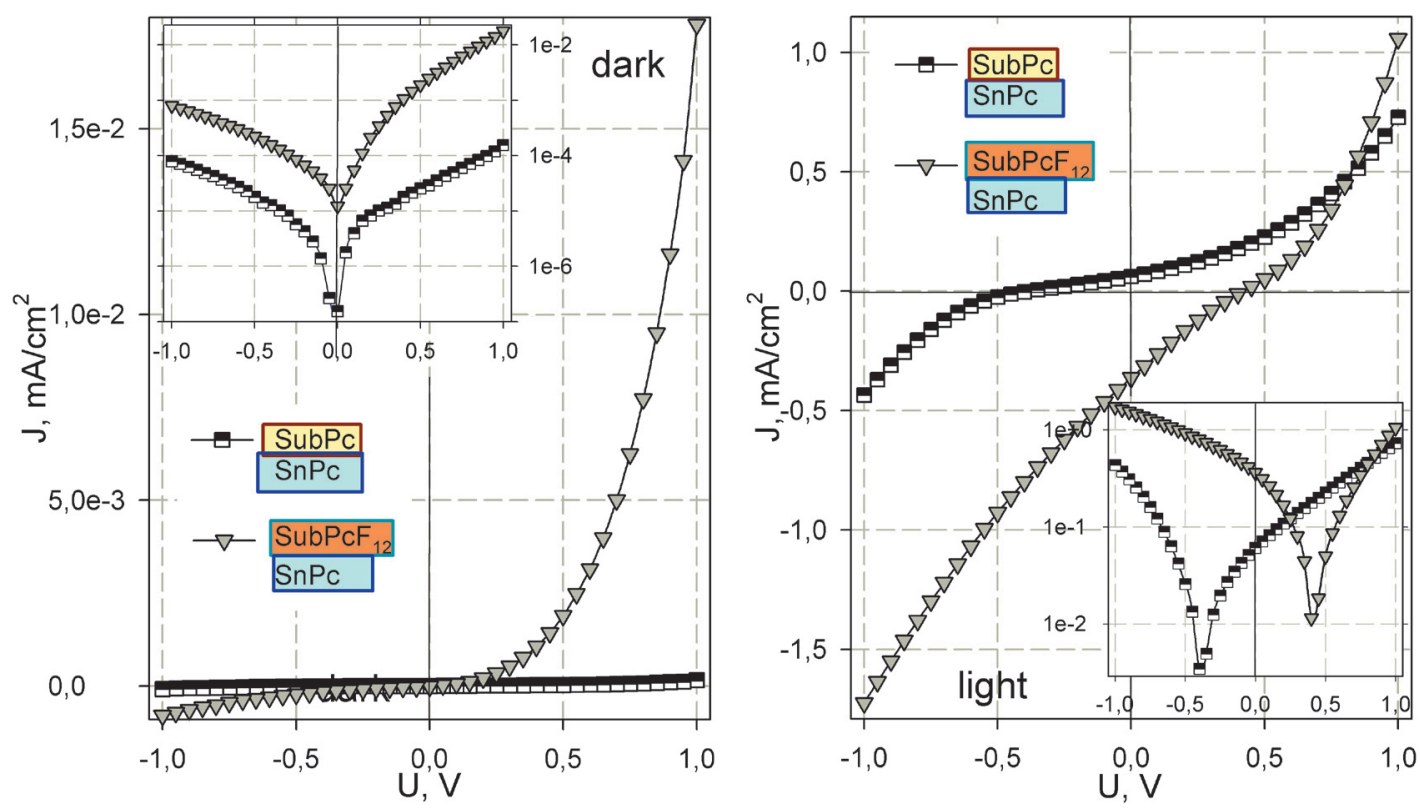

Figure 3. Comparison of $J-V$ characteristics of the devices with $\mathrm{SnPc} / \mathrm{SubPc}$ and $\mathrm{SnPc} / \mathrm{SubPcF}$ bilayers (in the dark - left panel, under illumination - right panel). The sequence of layers is depicted in the graph. For better comparison, the insets show the dependences redrawn in the semilog scale.

in Figure 2, although other explanations, like a drop of shunt resistance due to photoconductivity, are also possible. ${ }^{[7]}$

Next, the parent SnPc/SubPc junction was modified by replacing SubPc with $\mathrm{SubPcF}_{12}$, as shown in Figure 3. Now, the conventional molecular $p / n$ heterojunction is formed, therefore the $J-V$ dependences and photovoltaic parameters are close to those of the 'normal' photovoltaic cells (Table 1).

Comparison of the data in Figures 2 and 3 suggests that both $\mathrm{SnPc}$ and SubPc act as $p$-type semiconductors when paired with a standard $n$-type (acceptor) material, and contributions from the interfaces (parasitic Schottky junctions at the electrodes) are, indeed, not substantial. On the other hand, SubPc cannot be regarded as an 'acceptor' with respect to $\mathrm{SnPc}$ since the opposite sign of the photovoltaic effect for the $\mathrm{SnPc} / \mathrm{SubPc}$ junction is seen in Figure 1.

If so, the formation of an isotype $\mathrm{PHJ}$ between two molecular semiconductors SubPc and SnPc can be hypothesized, similarly to ${ }^{[2-4]}$. Here, the poorly conducting in the dark SubPc can be thought as $p$-type and a better 

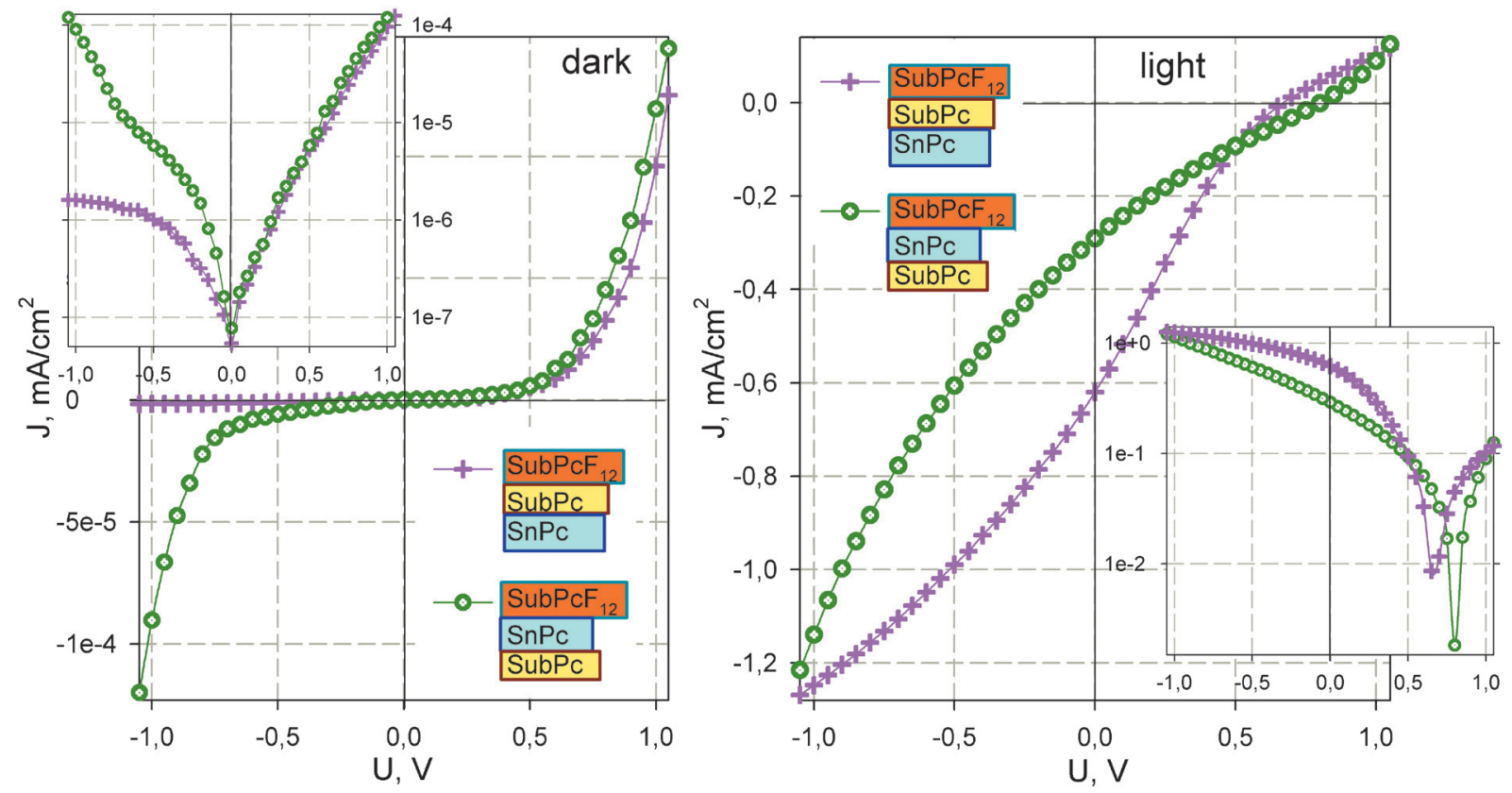

Figure 4. Comparison of $J-V$ characteristics of the devices with the tri-layer junctions (in the dark - left panel, under illumination - right panel). The sequence of layers is depicted in the graph. For better comparison, the insets show the dependences redrawn in the semilog scale.

conductive SnPc as P-type component. A characteristic feature of isotype junctions is non- (or weakly) rectifying behavior in the dark, ${ }^{[26]}$ although its forward and reverse $J$ - $V$ dependences obey different laws. However, it becomes photovoltaically active under illumination (Figure 1,S4), possibly due to the largely increased concentration of photogenerated charge carriers in SubPc. More information on the fundamental properties of these molecular semiconductors is needed to draw the relevant band diagram of the heterojunction at thermal equilibrium. ${ }^{[26]}$ The accumulation of charge carriers and band bending in the $p-p$ isotype heterojunction between a 3-unit phenanthrene (wide band-gap semiconductor) and vanadyl phthalocyanine (narrow band-gap semiconductor) is described in Ref. ${ }^{[3]}$ Similarly we can assume that the built-in field arises at the interface between SnPc (narrow band-gap) and SubPc (wide band-gap), which facilitates the dissociation of excitons in the illuminated devices thus giving rise to the photocurrent.

Finally, tri-layer structures were similarly fabricated and tested. Figure 4 shows the $J-V$ characteristics for the $\mathrm{SnPc} / \mathrm{SubPc} / \mathrm{SubPcF}_{12}$ and $\mathrm{SubPc} / \mathrm{SnPc} / \mathrm{SubPcF}_{12}$ multijunctions. The former case resembles the cascade architecture in the way that SubPc can be an acceptor with respect to SnPc and a donor with respect to $\mathrm{SubPcF}_{12}$. And indeed, the highest photocurrent among all of the tested devices was detected in this case (Table 1). The illuminated $J-V$ dependences for two sub-junctions, $\mathrm{SnPc} / \mathrm{SubPcF}_{12}$ and $\mathrm{SubPc} / \mathrm{SubPcF}_{12}$, are shown in Figure S6. The photovoltage in the tri-layer $\mathrm{SnPc} /$ $\mathrm{SubPc} / \mathrm{SubPcF}_{12}$ device is lower than in the reference bilayer cell without $\mathrm{SnPc} / \mathrm{SubPc}$ junction, indicating its negative function in such a sequence of layers.

The latter case, $\mathrm{SubPc} / \mathrm{SnPc} / \mathrm{SubPcF}_{12}$ is essentially a modification of the $\mathrm{SnPc} / \mathrm{SubPcF}_{12}$ bilayer from Figure 3 (triangles) by introducing SubPc at the bottom electrode $\left(c f .{ }^{[14,17]}\right)$. The value of $V_{o c}$ decreases by $0.14 \mathrm{~V}$ compared to the other trilayer device (Table 1), which suggests the 'open' state of the $\mathrm{SubPc} / \mathrm{SnPc}$ photodiode (Figure 1). It is unclear why the dark rectification disappears and the value of $J_{s c}$ does not increase in this case (Figure 4). Probably, there are limitations of the transport of charge carriers across the $\mathrm{SubPc} / \mathrm{SnPc}$ interface (accumulation). Besides, the conductive pathways in the multilayer thin-film cascade could be combined. For instance, the parallel electrical functioning of junctions (photodiodes) in the trilayer cascade solar cell was found in ${ }^{[7]}$, despite their spatial position in series.

\section{Conclusion}

The significant photovoltaic effect arises at the SubPc/ MetPc interface. This interface should most likely be considered as an isotype $p$-/P junction since both kinds of thin-film materials are the $p$-type semiconductors at the given conditions. Such a junction alone cannot be expected to produce high power conversion efficiencies since the photocurrents are quite low. Nonetheless, the photovoltage can be as high as $0.44 \mathrm{~V}$ for the devices incorporating the $\mathrm{PbPc} / \mathrm{SubPc}$ bilayer. This fact adds diversity to the concept of cascade in the multijunction solar cells, associated basically with the excitation transfer. Alternatively, such an isotype junction existing within the cascade can play a role of additional serially connected photodiode, polarity of which affects either $V_{o c}$ or $J_{s c}$, or both.

Acknowledgements. This work was supported by the RSF grant \#17-13-01522. 


\section{References}

1. a) Cnops K., Zango G., Genoe J., Heremans P., MartinezDiaz M.V., Torres T., Cheyns D. J. Am. Chem. Soc. 2015, 137, 8991-8997; b) de la Torre G., Bottari G., Torres T. Adv. Energy Mater. 2017, 7, 160170.

2. Li Y., Lv W., Luo X., Sun L., Zhou M., Zhang J., Zhao F., Zhong J., Peng Y. EPL 2015, 110, 17006.

3. a) Wang H., Wang X., Yu B., Geng Y., Yan D. Appl. Phys. Lett. 2008, 93, 113303; b) Wang H., Wang X., Huang H., Yan D. Appl. Phys. Lett. 2008, 93, 103307.

4. Forrest S.R., Leu L.Y., So F.F., Yoon. W.Y. J. Appl. Phys. 1989, 66, 5908.

5. Sista S., Yao Y., Yang Y., Tang M.L., Bao Zh. Appl. Phys. Lett. 2007, 91, 223508.

6. Cnops K., Rand B.P., Cheyns D., Verreet B., Empl M.A., Heremans P. Nat. Commun. 2014, 5, 4406.

7. a) Barito A., Sykes M.E., Bilby D., Amonoo J., Jin Y., Morris S.E., Green P.F., Kim J., Shtein M. J. Appl. Phys. 2013, 113, 203110; b) Barito A., Sykes M.E., Huang B., Bilby D. $A d v$. Energy Mater. 2014, 4, 1400216.

8. a) Morse G.E., Gantz J.L., Steirer K., Armstrong N.R., Bender T.P. ACS Appl. Mater. Interfaces 2014, 6, 1515-1524.; b) Castrucci J.S., Garner R.K., Dang J.D., Thibau E., Lu Z.-H., Bender T.P. ACS Appl. Mater. Interfaces 2016, 8, 24712-21.

9. Stevens M.A., Arango A.C. Org. Electron. 2016, 37, 80-84.

10. Huang J., Yu J., Guan Z., Jiang Y. Appl. Phys. Lett. 2010, 97, 143301.

11. Dai J., Jiang X., Wang H., Yan D. Appl. Phys. Lett. 2007, 91, 253503.

12. a) Schlenker C.W., Barlier V.S., Chin S.W., Whited M.T., McAnally R.E., Forrest S.R., Thompson M.E. Chem. Mater.
2011, 23, 4132-4140; b) Ichikawa M., Takekawa D., Jeon H.-G., Banoukepa G.D.R. Org. Electron. 2013, 14, 814-820.

13. Kumar H., Kumar P., Bhardwaj R., Sharma G.D., Chand S., Jain S.C., Kumar V. J. Phys. D: Appl. Phys. 2009, 42, 015103.

14. Li N., Lassiter B.E., Lunt R.R., Wei G., Forrest S.R. Appl. Phys. Lett. 2009, 94, 023307.

15. Chandran H.T., Ng T.-W., Foo Y., Li H.-W., Qing J., Liu X.-K., Chan C.-Y., Wong F.-L., Zapien J.A., Tsang S.-W., Lo M.-F., Lee C.-S. Adv. Mater. 2017, 29, 1606909.

16. Lin C.-F., Liu S.-W., Lee C.-C., Sakurai T., Kubota M., Su W.-C., Huang J.-C., Chiu T.-L., Han H.-C., Chen L.-C., Chen C.-T., Lee J.-H. Sol. Energy Mater. Sol. Cells 2015, 137, 138-145.

17. Sakurai T., Ohashi T., Kitazume H., Kubota M., Suemasu T., Akimoto K. Org. Electron. 2011, 12, 966-973.

18. Endres J., Pelczer I., Rand B.P., Kahn A. Chem. Mater. 2016, 28, 794-801.

19. Pakhomov G.L., Travkin V.V., Khamdoush M., Zhabanov Y.A., Stuzhin P.A. Macroheterocycles 2017, 10, 548-551.

20. Travkin V.V., Luk'yanov A.Yu., Drozdov M.N., Vopilkin E.A., Yunin P.A.,. Pakhomov G.L. Appl. Surf. Sci. 2016, 390, 703-709.

21. Travkin V.V., Stuzhin P.A., Okhapkin A.I., Korolyov S.A., Pakhomov G.L. Synth. Met. 2016, 212, 51-54.

22. Beaumont N., Castrucci J.S., Sullivan P., Morse G.E., Paton A.S., Lu Z.-H., Bender T.P, Jones T.S. J. Phys. Chem. C 2014, $118,14813-14823$.

23. Brédas J.-L. Chem. Mater. 2017, 29, 477-478.

24. Greiner M.T., Helander M.G., Tang W.-M., Wang Z.-B., Qiu J., Lu Z.-H. Nature Mat. 2012, 11, 76-81.

25. Yasuda T., Tsutsui T. Mol. Cryst. Liq. Cryst. 2007, 462, 3-9.

26. Sze S.M., Ng K.K. Physics of Semiconductor Devices, $3^{\text {rd }}$ ed., New Jersey: Wiley, 2007. 815 p. 